\title{
Life Guidance Meaning of Senthong
}

\author{
Siti Badriyah ${ }^{1}$ \\ Program Study Art Creation and Art Study, Post Graduate Program of Indonesian Institute of The Arts (ISI) \\ Surakarta, Jl. Ki Hadjar Dewantara no. 19 Jebres
}

Dharsono $^{2} \quad$ Nanik Sri Prihatini $^{3} \quad$ Arya Ronald $^{4}$

\begin{abstract}
Senthong loaded with philosophical meaning behind their performance. This assessment is very important to be explored on the phenomenology behind the system layout that was held in the hierarchy, especially Senthong kiwo have the implied meaning behind the role and the procession along with the symbols that complements the room, it's a part of interior dalem in traditional Javanese house. As well as trying to explore the meaning behind the visual expression which appears through the analysis of the existence of spatial interior senthong system? Where the spatial planning system is configured of analysis (tangible culture) of user activity on the function space and Javanese culture values. This assessment of dalem with filosophis that "aku/dalem:saya" related to Javanese culture values. This constructions of its minds that formulate a determinant factor in performance and designing the interior of a dalem, thus grounding the disclosure order of function. Form and construction of the space can be easily understood in relation to the nature and behavior of space. The purpose of this assessment is to obtain a definition of the ideal grounding system layout senthong development, in such a way as to be known visual signs and various emblems attached to the office system through the analysis of symbolic interaction. As well as the research methods that include data collection in the field survey techniques include interviews, field observations (observation) and documentation. Physical data (sample) in the form of artifacts (the category of traditional Javanese house, the characteristics of users, daily activities, ritual activities, layout, layout space conditions, physical characteristics of the building (age, material, ornamentation, color and originality). Sampling by deliberation chose building with the following criteria: 1) the building still has the original interior dalem or experiencing a fundamental alteration, and are well preserved; 2) The building is still in the age category above 50 years (160 years).
\end{abstract}

Keywords: senthong, spatial system, life guidance meaning

DOI: $10.7176 / \mathrm{ADS} / 74-01$

Publication date:June $30^{\text {th }} 2019$

\section{Introduction}

The study of the existence of senthong in the Javanese cultural system which is related to the comfort value of space. The existence of senthong is part of dalem interior of traditional Javanese houses. The focus of the study on effectiveness (usability value) of senthong is related to user activity (with gender specifications), and facilities used in the shade of Javanese culture. Effectiveness or appropriateness value is according to the Indonesian Dictionary, the word effective means effects, influence, result or can bring results. So, effectiveness is activeness, usability, the suitability in an activity of the person carrying out the task with the intended target (nguwongke uwong).

Effectiveness basically shows the level of achievement of results, often or always associated with the understanding of efficiency, even though there are actually differences between the two. Effectiveness emphasizes the results achieved, while efficiency looks more at how to achieve the results achieved by comparing the input and output (Siagaan, 2001: 24) .

The life of Javanese people presents a very unique cultural attraction, namely the pattern of life behavior in a space that has a cultural background (insight, social level, education, aesthetics) occupants in the context of Javanese culture loaded with messages implicitly addressed to the next generation as a life guideline. The context of this study will be within the scope of Javanese culture, this will provide clear signs and limits for the scope of the study. Senthong is part of the dalem interior in a Javanese house which has three parts of space, each of which has different functions and meanings. The form of spatial planning will involve physical aspects such as the composition of space, application (choice of materials, furniture settings, circulation, body size / anthropometry, ornamentation, color and textures) while non-physical forms will be related to aspects of norms, kejawen mysticism, philosophy and myths accompanying the existence of a senthong interior appearance.

\footnotetext{
${ }^{1}$ Interior Design Lecturer at Indonesian Institute of the Arts, Surakarta

${ }^{2}$ Postgraduate Lecturer at Indonesian Institute of the Arts, Surakarta

${ }^{3}$ Postgraduate Lecturer at Indonesian Institute of the Arts, Surakarta

${ }^{4}$ Postgraduate Lecturer at Indonesian Institute of the Arts, Surakarta

5 http://literaturbook.blogspot.co.id/2014/12/pengertian-efektivitas-dan-landasan.html (downloaded by Badriyah, December 19 2017, 12.45)
} 
Senthong has a simple visual condition in the form of rectangular chambers that are symmetrically compiled, where effectiveness will be achieved if appropriate, meaning that it is oriented towards maximizing the achievement of the goals of each senthong in its spatial system.

The urgency of this paper will be very useful in conservation efforts to lay the foundation and formulate a Javanese house layout system as a wealth of visual culture of the Indonesian people. Scientific writing must be carried out immediately, because artifacts as traces of cultural heritage are increasingly extinct with age, whereas the existence of artifacts is a real trace that implies a message from the ancestors of future generations of culture. The moral message and physical existence are very worrying if the conditions are not maintained because it will be difficult to reveal the veils on the artifact.

The extra aesthetic aspects implied behind its existence, such as the basis of design in the concept of placing humans as occupants, physical, psychological and ideological suitability, where core achievement of space effectiveness if functional indicators, usefull, convenience, comfortable, esteis are well integrated in spatial systems. Functional means that every space in the senthong system functions according to the purpose of its creation, usefull means being able to fulfill the functions of each function that runs, convenience means being able to give a sense that matches its function, if appropriate means happy feelings that are occupying, being comfortable means comfortable physically and psychologically, able to adapt to the conditions of the body of the occupants, the aesthetics here are more about the arts that are sacred, meaning that the existing visualization is able to provide inner calm and be able to deliver to true perfection. This topic will be an explorative writing and an interesting cultural attraction to be revealed both in terms of physical and non-physical culture within the scope of Javanese community occupation, so it is very feasible to be studied as a study that is able to visually describe the cultural structure as a space that full of meaning as a guidelineof life for future generations.

Senthong's performance is strongly influenced by the type of house and whose house it belongs to is. The interior of Senthong Javanese houses has a visual difference in appearance. How are the forms that exist in senthong interior layout (both forming elements, elements of filler and decoration).Based on the description above, the fundamental problems of this study topic are as follows:

1. How is the foundation of the ideas of the spatial system, functions and cultural attractions that occur in Senthong as life guidance is able to represent the philosophy of life for Javanese people?

2. What is the nature of the effectiveness of senthong spatial system and the determinants factor that shade the visual culture in the senthong spatial system of traditional Javanese houses in Surakarta?

\section{Purposes}

The purposes of this research are:

a). To formulate the foundation of ideas for creating a senthong spatial system in such a way, so that the visual signs and various symbols attached to its spatial system can also be known, explaining in an explanatory way the interesting side of Javanese cultural attractions (which imply the Javanese view of life) occur on senthong that is able become a guide for the next generation of the nation and be able to become a source of ethnic wealth of the Indonesian people in increasing the competitiveness of the Indonesian people in the eyes of the International world, and can be used as an attempt to develop ways to maintain its sustainability

b). To obtain knowledge of the effectiveness of the senthong spatial system and formulating the determinants factor that shade the visual culture in the senthong spatial system of traditional Javanese houses so that it can guide the generation of the nation.

\section{Research Method}

a. Pattern of Thought

Starting from the benchmarks of Javanese cultural philosophy, ideas emerged in the material culture that existed in the realm of ideas between the dimensions of use and image by the owner (head of household) and the dimensions of life in the inner format of Javanese manifesting in ideology of senthong spatial system which measures the effectiveness of the system.

b. Theoretical / Conceptual Framework

Based on the intellectual ability of the head of the household in a single life together with husband and wife shaded by Javanese beliefs, namely the ideology of kejawen and Javanese cosmology and his life view will reveal the values inherent in the senthong spatial system, to further form the value of individual personality which later shifts to the value of the personality of the household concerned. The intellectuality of the inhabitants, their beliefs and views of life mingle with each other in the ideology of their spatial systems, where the value of effectiveness will be based on an analysis of their ideological excavation.

c. Research Method

To find qualitative formulas that are relating to the concept of spatial system in Javanese household, as well as an effort to apply household values in the house atmosphere in general and senthong spaces in particular. It is carried out by comparative studies among several Houses of Kepengeranan in the Keraton Kasunanan Surakarta 
Hadiningrat area, with the understanding that the results of comparison will be a framework to formulate spatial system concepts and the nature of its effectiveness are formulated fundamentally descriptive.

d. Research Process

As an illustration of a unity with the analogy of the human body there are interrelated metabolism in work functions, if each functional component will be identified as effective and give birth to prosperity as senthong with the part of space in the ndalem will function in the wheel of life. So that it will emphasize life that runs continuously in the changing dynamics of life as an effort to adjust to actual life needs.

\section{Results and Discussion \\ I. Introduction}

A Javanese man will be considered perfect in his life if he has five conditions, namely wisma (house), turangga (horse), kukila (bird), wanodya (wife) and curiga/kris (Musman 2017,1). The house as the first condition and is considered standard for Javanese men, is considered a symbol of authority and social status. Especially for a pengeran, it becomes a proud thing and a symbol of authority as a ruler in a region of government. Visualization of Ndalem Kapangeran reflects the ideology of the ndalem spatial system, where the ideology indicates the effectiveness of its spatial system, as well as senthong, which is the core of the metabolic system of the ndalem, becomes a standard in the ndalem kapangeran structure.

\section{The Ideal Platform for Creating Senthong Interior Spatial Systems}

Humans are born to know the environment starting from home which is an important aspect for the beginning of human life. It is the media for the development of human body and soul in the realm of education to develop mindsets and skills. Daily phenomena will foster the moral and spiritual values of one's soul, which are conditioned to be specific personality in such a way that they are able to stand up to the abilities provided at home. Every visual element structure forms a unified entity. Home as a configuration of the fabric of life phenomena (behavior) and ideology, which later emerged as cultural attractions of certain ethnic communities.

The house as this precious product, not only as the design of visual beauty both architecture and interior, but more than that is a reflection of the outlook on life, understanding the values and norms of Javanese cultural society towards the existence of the house as a whole. The complex meanings of life and the high value inherent in the home are manifestations of existence in nothingness. Therefore, this precious product needs to be explored more deeply and needs to be examined more closely, so that the object of the house at one time can occupy its role as the subject of the house with the understanding that the house is a mirror image of the human being.

The technical and philosophical requirements relating to material in home that become Javanese people's beliefs are absolutely essential. Along with the development of the era, it turns out that it continues to experience changes in accordance with the demands of life and environmental conditions, which basically strive to achieve balance, continuously throughout time, memayu hayuning bawana becomes a driving force to be consistent with this attitude.

Aspects relating to the dalem interior spatial system especially senthong include spatial layout, flow of circulation, functions and activities, symbols and decoration. The important aspects of Senthong make the Senthong entity an interesting cultural attraction to be drawn to the surface. Cultural attractions represent cultural values and shade the presence of senthong interiors for Javanese people. The owner's social status from nobility to ordinary people will affect the appearance of each type of traditional Javanese house. The shape of his house has a level ranging from joglo to kampung. This category influences spatial patterns and architectural elements that convey certain roles and symbols. The scope of the function of the building is a residence. The architectural elements are divided into filling elements, limiting elements and complementary elements of space as Cahyandari stated in (Markus et al, 1972).

Javanese Traditional Houses consist of several spaces created based on the need to fulfill activities and functions, interests, beliefs and philosophy of life. Every room has a name which in a language contains philosophical meanings that are believed to exist. As Ismunandar $(2007,104)$ said, the spatial configuration of traditional Javanese houses, especially Joglo, consists of a spatial arrangement divided into three main parts, namely a meeting room called pendapa, the middle room or space used to hold a puppet show called pringgitan or kampung, and the third is the back room called dalem as a family room. In that room there are three sentong (rooms), namely senthong kiwa, sentong tengah and senthong tengen. 


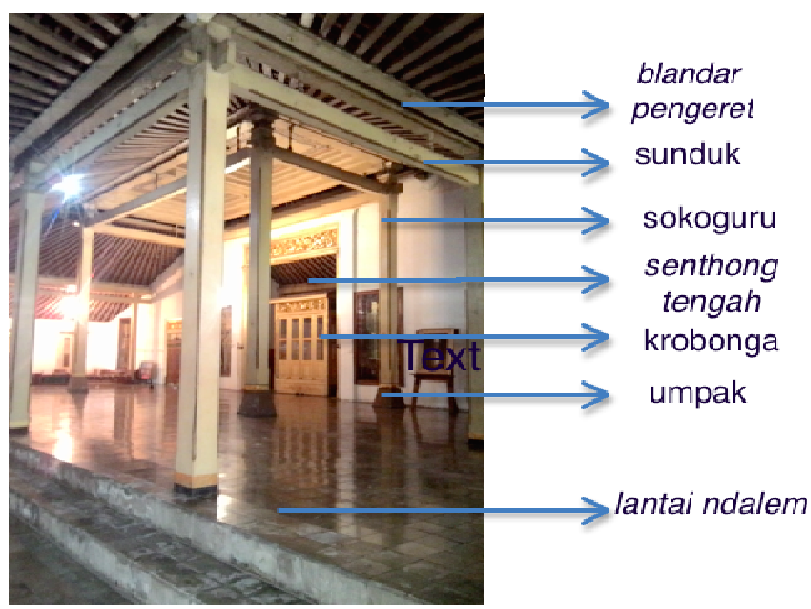

Picture 1.Interior of Ndalem Kapangeranan Sasono Mulyo

(Photo: Documentation by Siti Badriyah, 2017)

The configuration of Senthong itself is very interesting from the point of view of the issue of function, domestic authority and philosophy. Senthong is a characteristic that marks the existence of Javanese traditional houses, by revealing their existence both from the spatial system and the philosophical meanings contained in senthong. Dalem interior of the house of priyayi (upper class society) as stated by Sunarmi et al $(2007,48)$ that there are provisions imposed by the general public that it is not permissible to make a 'Joglo' or 'Limasan' house resembling a palace, because of the physical presence has a balance in positioning between spaces.

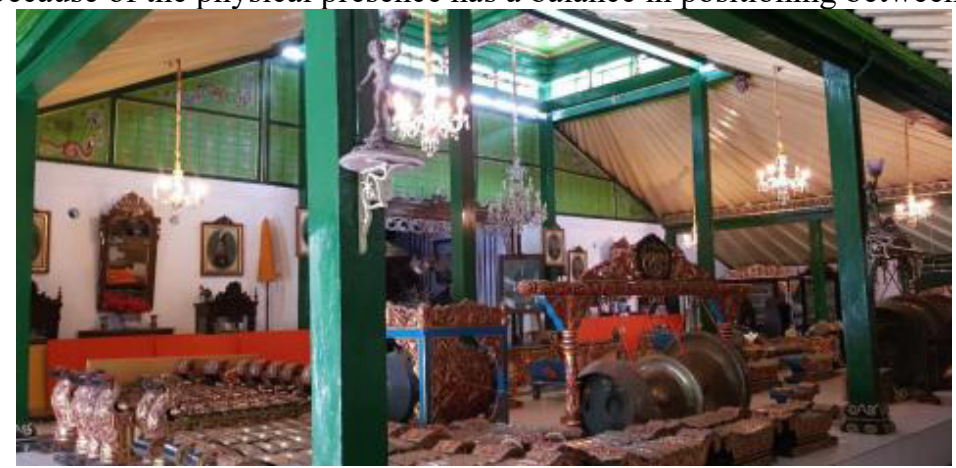

Picture 2.The appearance of senthong from dalem area

(Photo: Documentation by Siti Badriyah, 2018)

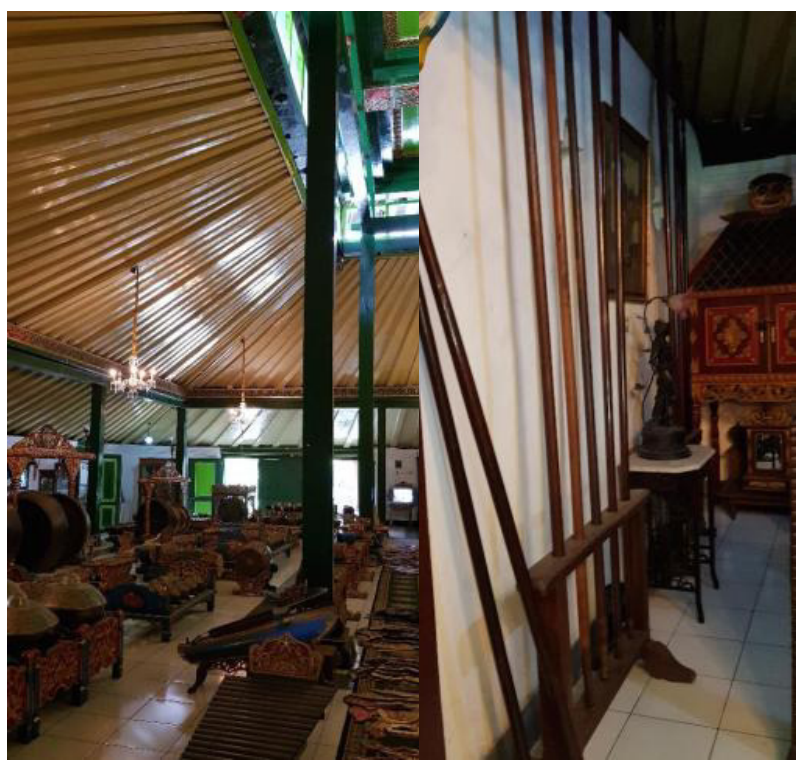

Picture 3. Some of the dalem areas are directly connected to Senthong, and weapons in the back area of Krobongan / Senthong tengah (Photo: Documentation by Siti Badriyah, 2018) 


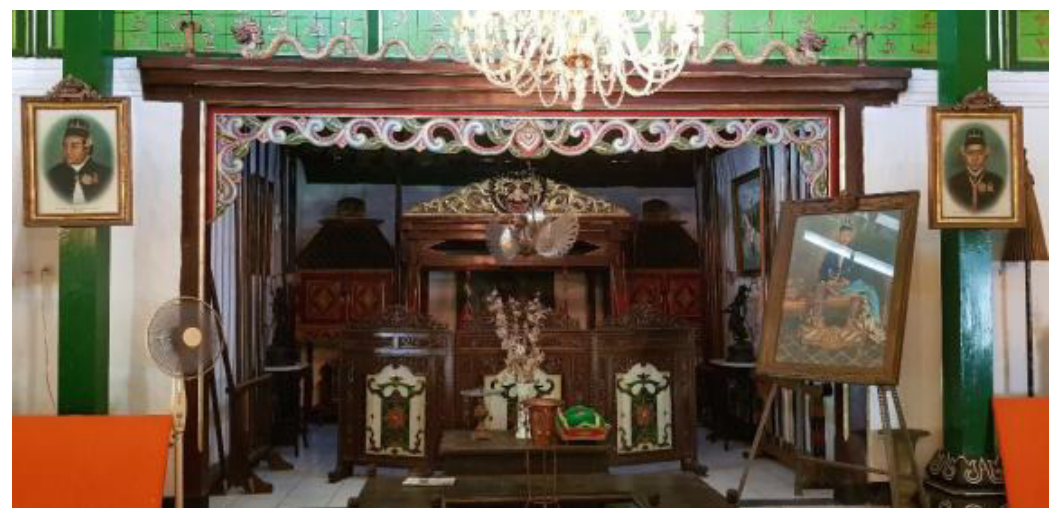

Picture 4. Appearance of senthong tengah area with krobongan

(Photo: Documentation by Siti Badriyah, 2018)

Senthong tengah flanked by Senthong Kiwo and Tengen is the composition of space that applies the principle of balance, which in the principles of interior design is one of the principles of organizing space that prioritizes symmetrical balance. Symmetrical balance in the Javanese spatial structure has a planning basis that is related to life views and has its own philosophical meaning. Symmetrically structured spatial systems have a function of the level of authority in accordance with the level of privatization. Each space from front to back has a philosophical meaning in the life of the Javanese community, which is able to be seen visually in the form of visual expression (spectacle) but also implies a philosophical meaning that is able to guide or direct behavior (life behavior) for its owner (guidance).

\begin{tabular}{|l|l|l|l|l|l|}
\hline Type of Room & $\begin{array}{l}\text { Material } \\
\text { Specifications }\end{array}$ & $\begin{array}{l}\text { Nature of } \\
\text { Room }\end{array}$ & Basic Form & Function & Type of Furniture \\
\hline Dalem & $\begin{array}{l}\text { Wall (wood / } \\
\text { brick), floor } \\
\text { (plaster/tile) }\end{array}$ & $\begin{array}{l}\text { Semi } \\
\text { Private }\end{array}$ & Rectangular & $\begin{array}{l}\text { A place for } \\
\text { family to } \\
\text { gather / } \\
\text { discuss }\end{array}$ & $\begin{array}{l}\text { Chairs, tables, mats, } \\
\text { display cabinets, } \\
\text { sketches }\end{array}$ \\
\hline Senthong kiwo & $\begin{array}{l}\text { Wooden } \\
\text { wall/gebyok }\end{array}$ & Private & Rectangular & Garwapadmi & $\begin{array}{l}\text { Bed, wardrobe, } \\
\text { dressing table }\end{array}$ \\
\hline $\begin{array}{l}\text { Senthong tengah/ } \\
\text { krobongan }\end{array}$ & $\begin{array}{l}\text { Wooden wall / } \\
\text { gebyok }\end{array}$ & $\begin{array}{l}\text { Super } \\
\text { Private }\end{array}$ & Rectangular & Ritual area ${ }^{1}$ & $\begin{array}{l}\text { A set of beds, } \\
\text { complete with } \\
\text { pillows and bolsters }\end{array}$ \\
\hline Senthong tengen & $\begin{array}{l}\text { Wooden wall / } \\
\text { gebyok }\end{array}$ & Private & Rectangular & Pengeran & Bed, cabinet \\
\hline
\end{tabular}

Table 1. Spatial system (activity, form and filler of space) Ndalem Kapangeran Sasana Mulya Surakarta interior (Source: Siti Badriyah, 2016)

\begin{tabular}{|l|l|l|l|l|}
\hline $\begin{array}{l}\text { Type of } \\
\text { Room }\end{array}$ & Light Element & $\begin{array}{l}\text { Air } \\
\text { Element }\end{array}$ & Acoustic Element & $\begin{array}{l}\text { Circulation Pattern of } \\
\text { Activity }\end{array}$ \\
\hline Dalem & $\begin{array}{l}\text { - natural (afternoon) } \\
\text {-electric light } \\
\text { (night) }\end{array}$ & Natural & $\begin{array}{l}\text { Use of ornamental plants in } \\
\text { the outer space \& shade } \\
\text { trees }\end{array}$ & $\begin{array}{l}\text { Radial (this space is a } \\
\text { central area of several } \\
\text { spaces) }\end{array}$ \\
\hline $\begin{array}{l}\text { Senthong } \\
\text { kiwo }\end{array}$ & $\begin{array}{l}\text { - natural (afternoon) } \\
\text {-electric light } \\
\text { (night) }\end{array}$ & Natural & $\begin{array}{l}\text { Use of ornamental plants in } \\
\text { the outer space \& shade } \\
\text { trees }\end{array}$ & $\begin{array}{l}\text { Defensive (1 door to enter } \\
\text { and exit) }\end{array}$ \\
\hline $\begin{array}{l}\text { Senthong } \\
\text { tengah }\end{array}$ & $\begin{array}{l}\text { - natural (afternoon) } \\
\text {-electric light } \\
\text { (night) }\end{array}$ & Natural & $\begin{array}{l}\text { Use of ornamental plants in } \\
\text { the outer space \& shade } \\
\text { trees }\end{array}$ & $\begin{array}{l}\text { Defensive (1 door to enter } \\
\text { and exit) }\end{array}$ \\
\hline $\begin{array}{l}\text { Senthong } \\
\text { tengen }\end{array}$ & $\begin{array}{l}\text { - natural (afternoon) } \\
\text {-electric light } \\
\text { (night) }\end{array}$ & Natural & $\begin{array}{l}\text { Use of ornamental plants in } \\
\text { the outer space \& shade } \\
\text { trees }\end{array}$ & $\begin{array}{l}\text { Defensive (1 door to enter } \\
\text { and exit) }\end{array}$ \\
\hline
\end{tabular}

Table 2.The spatial system (lighting, air conditioning, acoustics) of the interior of Ndalem Kapangeran Surakarta (Source: Siti Badriyah, 2016)

The peculiarity of Javanese traditional houses has a senthong space system as part of a sacred house and has

\footnotetext{
${ }^{1}$ As a sacred place "mbok sri”, usually there is a bed complete with offerings such as betel, jugs filled with water, food, porridge (jenang), incense and flowers (interview with Gusti Puger Puspoyo, Tuesday, December 26, 2016, 11:50 WIB)
} 
the highest spiritual value. Senthong has a space composition consisting of Senthong Tengah, Senthong Tengen and Senthong Kiwo. The functions of Senthong Tengen and Senthong Kiwa as bedroom and Senthong Tengah as ritual spaces where Krobongan is located (Wicaksono 2014,40). The senthong spatial system besides being implemented in the division of space along with local authority levels, also the application of symbols, colors and ornament forms. The system itself comes from Latin (systema) and Greek (sustema) is a unit consisting of components or elements that are connected together to facilitate the flow of information, material or energy to achieve a goal ${ }^{1}$. Dalem is a private space which is one of its functions as a space for gathering all family members.

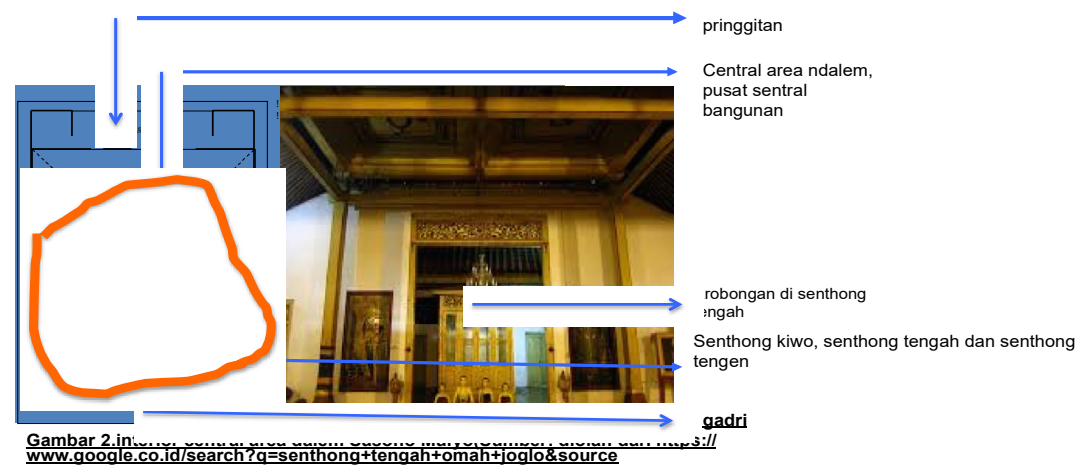

Picture 5. Interior central area in Ndalem Sasana Mulya Surakarta, as focusing study

(from: Https//www. google co.id/search?q:senthong+omah+Joglo\& Source, accessed by Badriyah: Thursday, December 23, 2016, 12.30 WIB

The interior of Senthong in this case will be analyzed starting from components or elements that collaborate with each other in a single unit space function and philosophical meaning. Senthong is square with a space forming element consisting of the back of a brick or wood wall, the left and right sides can be wood or brick, while the front part is usually from a wooden board panel (depending on the type of house). Floors (Jerambah) also use materials that depend on the category of type of room and house. The application of terrazzo material is commonly used among the nobility and priyayi in the category of Joglo and Limasan houses, while the use of land as a floor without finishing for the category of kampong houses (Djono, 2012: 274).

Ornaments and symbols are two things that are interrelated, because the shape of the ornament is a symbol that implies a view of life that represents the life order that is the inner life of the Javanese. Ornaments of Javanese traditional buildings include flora, fauna, and nature and religion ornament. As stated (Sunarmi, 2007: 113) that the basic concept of ornament is to decorate something to make it more beautiful. The meaning of beautification as a derivative of the ornament has a variety of coverage, because the ornament is not only contained on the surface of two dimensions, but also on the surface of three dimensions. Ornament has a close relationship with various products from beautifying activities. Ornamental flora cannot be separated from the influence of pre-Islamic times (Hindu era). The flora used as an ornament in traditional Javanese buildings has a sacred meaning. Ornamental flora has more type. The meaning of this ornament is the beauty and goodness of red, green, and golden yellow, (Cahyandari, 2012: 105).

The laying of ornamental patterns spread on several interior elements both organic and non-organic, also on structural architecture in each space, with the application of philosophical considerations. The Javanese man when he was going to build a house accompanied by prayer and hope that the house he built would be a source of happiness and prosperity as well as peace of mind for the owner. So that the tangibled and non-tangible factors always complete the process. The application of symbols through ornament and other visual elements is a reflection of the expectations of homeowners.

\footnotetext{
${ }^{1}$ https://id.wikipedia.org/wiki/Sistem, accessed by Badriyah: Thursday, December 22, 2016, 11.30 WIB
} 


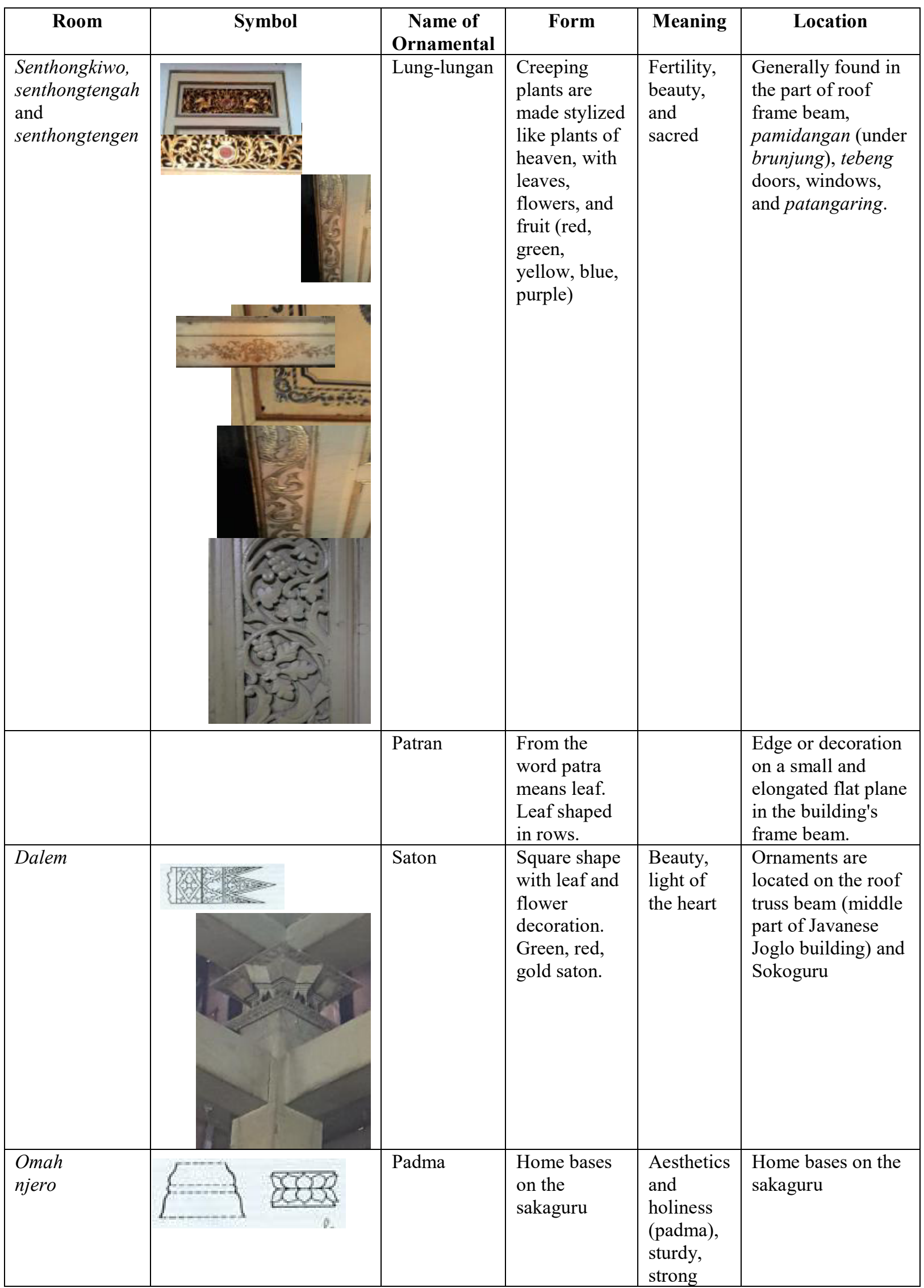

Table 3.Ornamental Variety, Symbols and Meanings in the Ndalem Interior of the House of Kapangeran Sasana Mulya Surakarta (Source: Siti Badriyah, 2016) 


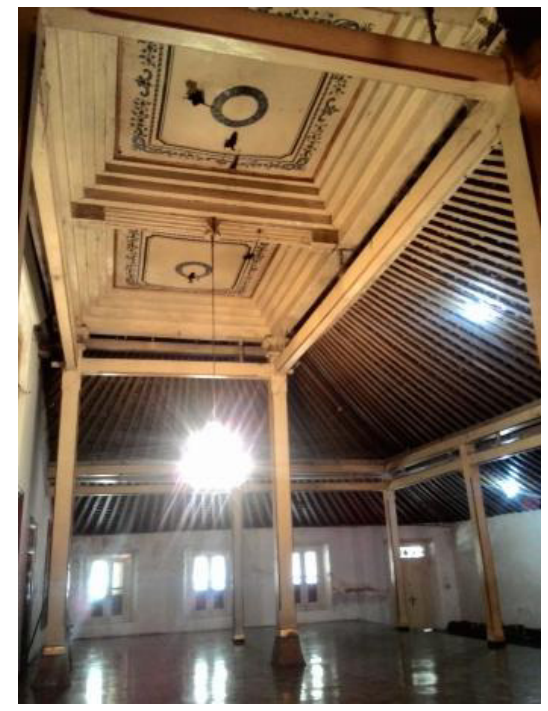

Picture 5. Appearance of Saka guru on the Interior of dalem Sasana Mulya (Photo: Documentation by Siti Badriyah, 2016)

\section{A View of Life That Attach to Senthong}

Prijotomo has explained above that senthong is a space that has important meaning for Javanese society, both in function and meaning. Clear division and structured functions according to the meaning contained. Krobongan as a central room is a sacred area of the entire house. In addition, this area is also a place of prayer, ritual activities or meditation, while Senthong-Senthong is a family bedroom at night. The complexity of activities and functions of each space has consequences for its supporting components, both material and moral.The components of space formers, space fillers and spatial conditions are integrated into the harmony of human relationships between human inhabitants and their environment, human beings with nature and humans with their God (microcosm and macrocosm). This is also a composition of entities in harmony as expressed Sony Kartika $(2016,56)$ that harmony is a combination of different elements closely. If aesthetic elements are combined side by side, a certain combination will emerge and harmony will occur.

Parts of the room in a Javanese traditional house that is full of meaning and symbols will be understood that a life occured in this world will achieve perfection if a balance between worldly life and spiritual life is achieved. The study of the meaning of senthong interior spatial system is actually placed on the mindset and view of lifeof Javanese society. It means that all the components or elements that make up the structure of the spatial system, be it behavior, daily activities, and structured arrangement are in the context of fulfilling the needs of everyday life, which are summarized in the philosophy of his life. As stated (Budiwiyanto, 2010: 95) that in terms of housing arrangement, Javanese recognize a symbolic classification based on two, four, and eight.

The view of the two classifications that are often manifested by the upper and lower worlds, often combined with the middle world. The term is often expressed as loroning atunggal or kiwo-tengen. Between kiwo-tengen is combined by something bigger and absolute. Formulation of the ideal foundation of the ndalem development spatial system in particular, related to visual signs and various symbols attached to the spatial system which are connected with referring to the "Nguwongke uwong" life philosophy, among others, can be described as follows:

1. Dalem room is semi-private room (meaning some people who are still relatives can enter the room), in activities that are family discussion, while in incidental situations when there is a celebration, the room can be used by relatives to sleep relatives by holding a mat because the floor has a different height level from jogan or jerambah. The treatment of space (entry designation) and activities (sleep and family discussion) for users is a representation of the philosophy of "nguwongke uwong". The rationale in the concept of creating comfort in activities in that room has been applied significantly in everyday life for the Javanese people.

Each category of types of Javanese traditional houses will have a pattern and a dalem spatial system that is basically the same, while the decoration that appears is saton which is plastered on the central part of the Joglo house, saton itself consists of tumpal, tlacapan and sorot. The meaning contained is beauty, and the light of heart, the meaning implied is the existence of an expression of hope to reach the light of the heart when receiving trials and remain strong and sincere.

An attempt to apply the symbolic meaning behind this ornament of Saton in the hopes and inner demands to always be strong as a Javanese man, who always carries out his conduct of concern in living this life. This guidance is adaptive to the basic beliefs and ideology that has been handed down from generation to generation, which is ingrained. This means that the guidance implanted has no 
compulsion because it is subtly implied, and is already part of what has been believed regenerativey. The pattern of behavior and spiritual guidance is part of the Javanese philosophy "nguwongke uwong", appropriate to the users who are the target of the guidance (next generation).

2. Senthong Tengen is a private room, because only male families have the right to enter and sleep. The layout is formed from the setting of furniture for sleeping and wardrobe in a defensive pattern, meaning that the bed is in a position on the one side of corners of the room, showing the level of domestic authority for the space user in accordance with the appropriate social distance. The circulation flow that directs in and out of one door shows that personality is in activity.

The height of the door is also measured based on Javanese humans, by using the size of "sakawean", sometimes using cubit as well. This is the application of size to the anthropometry of Javanese humans. The decoration seen in the panel (gebyok) in the house is a type of lung-lungan that has meaning of fertility and beauty. The meaning of fertility is in every senthong because it shows reproductive activity which is sacred. It is the true function of the room.

The meaning that is applied is very appropriate for the existing activities; the condition of the room also accommodates the activities that occur in it. The conditions both lighting and air strongly support activities that occur both day and night. This shows a design with a mature concept based on the philosophy of life "nguwongke uwong" which applies the spatial conditions that are very conducive to the reproductive activities that occur in it.

3. Senthong Tengah (krobongan ${ }^{1}$ ) is a very private room; related to ritual activities, worship to Mbok Sri, Dewi Sri the goddess of rice. The layout that is set up with space fillers such as a set of beds complete with bolster and pillows, and offerings and two bunches of rice that have symbolic meanings shows a representation of conditioned ritual areas with dim lighting, natural ventilation of some bovling that is about the size of two inches will have an effect the natural light enters from the side of the back wall, while the ornament that is in the gebyok area is Lung-lungan with a little stylation. Lung-lungan means fertility which refers to the intended pattern of activity (reproduction) in carrying out offspring and the comfort of body and soul. The spatial system refers to a match between activity and user. The solemn rituals are represented through several uborampe offerings, and furniture sets were based on the philosophy of "nguwongke uwong" in prayer.

4. Senthong Kiwa is a private space because it is only allowed for female families. The set of this room is almost the same as senthong kiwo. It uses of a defensive pattern of sleeping area in one corner of the room with the flow of circulation in and out at one door. The existing decoration is also the same between senthong-senthong, namely Lung-lungan, which has the meaning of fertility. It emphasises more on sacral activity as a basic function for survival. It has the same basic design concept, namely the philosophy of "nguwongke uwong".

The condition aspects of each room thatis adapting to a tropical-characterized environment is an effort to adjust to the situation and conditions of tropical climates. The natural lighting that is very dominant in the daytime are very explored on the side of the wall, natural ventilation also adapts nature by reducing a lot of partition and extensive and volume roof cavity. This adjustment is based on the benefits obtained by residents from environmentally friendly nature (application of materials), this shows the foundation of the adopted philosophy"nguwongke uwong" which makes each piece of art adapted to the situation and conditions of the inhabitants and nature.

\section{Determining Factor that Shade the Visual Culture in Senthong Spatial Systems of Traditional Javanese Houses so as to Become a Guidance to the Nation's Generation}

The Javanese visual culture is unique that attracts the international community, especially in the senthong spatial system. The spatial system is based on several determining factor that the Javanese have in their lives and beliefs. The determining factors that describe the visualization that implies a life view and philosophy represents the hopes and orientation of Javanese life. The determining factors include:

- Kejawen ideology possessed by Javanese is a special feature that is able to provide a unique cultural pattern. Culture that is full of ideologies abstracted from Hinduism, Buddhism and Islam (syncretism). The visual and non-visual cultures are influenced by multicultural characters (Indian, Chinese and Arabic), this gives color to every detail of cultural activities.

- Cosmos ideology which is also a partial belief in the layers of Javanese society is socially constructive

\footnotetext{
${ }^{1}$ A special area in Javanese traditional house whose main function is to store a number of gaman or heirlooms that have magical powers. This space is also used by residents to pray to God or to meditate, Krobongan is a special room created as a tribute to Dewi Sri, who is considered to have a very important role in all aspects of Javanese people's lives, some ubo rampe for this room are beds, mattresses, pillows and bolsters. This object is not as a tool for sleep, but as a symbol of the union of love relationships between men and women. In addition to these objects, there is also a statue of Roro Blonyo which symbolizes the happiness and fertility of husband and wife. (Interview with Ms. Puspoyo, Tuesday, December 26, 2016, at 1:00 p.m. WIB)
} 
giving a strong belief in the forces of nature which are above human strength, so that nature becomes the dominant center of spiritual activity orientation (Ronald, 2005: 130-131).

- Some guidelines for life that are believed to be passed down through generations such as tepaslira, manners, life in morals, tolerance. A prominent feature of Javanese people is always trying to maintain a spiritual balance, showing themselves to be calm and refined and controlled (Handayani, 2004 179; Zaini 2011,244), contributing greatly in an efforts to preserve a natural ecosystem for the Javanese community.

The environment is in harmony with nature, which is the result of collaboration between the efforts to create harmony between humans and homes, and humans with their God (microcosm and macrocosm). For example, as stated (Ronald 2005, 145) that moral life begins with the smallest group, the nuclear family, between husband and wife, parents and children and between older children and younger ones.

If moral life becomes increasingly intense, then the light of the soul image of this family emerges. If these families who live in moral and dense life are in a neighboring environment that also lives like this, then this household group will form a society that has a concentrated soul. Thus, the glow of core moral will emerge from this environment, so that the characteristics of beauty, fairness, honesty, flexibility and superior politeness will emerge. Environmental characteristics that are formed from the attitude of Javanese society are strongly believed in designing dalem interior system; this shows contextual entities in a specific category to be immediately written as an effort to conserve traditional house architecture.

- The balance of society in carrying out kejawen and cosmos ideology is an important factor that overshadows the visual culture in the senthong spatial system of Javanese traditional house. Some elements of visual culture such as the pattern of arrangement of rooms, spatial systems, symbolic forms and implied meanings are part of the representation of the Javanese philosophy of life. It is as a form of mindset for generations of nation who use messagesfrom ancestors as a foundation in cultural conservation efforts.

\section{Conclusion}

Based on the explanation, it can be concluded that:

1. The ideal foundation for creating a senthong interior spatial system,among others, trust, philosophy of life and adaptation to the cosmos (life balance). The foundation underlies the senthong spatial system besides being implemented in the division of space along with the level of local authority, as well as the application of symbols, colors and ornament forms. Javanese Traditional Houses consist of several spaces created based on the need to fulfill activities and functions, interests, beliefs and philosophy of life. Every room has a name which in a language contains philosophical meanings that are believed to exist.

2. The view of life inherent in senthong is explained in the visualization of senthong, which in principle becomes three important aspects, namely:

- The nguwongke uwong philosophy is the basis for the disclosure of spatial systems, functions, the nature of room, forms, ornament and behavior or activities in senthong interiors.

- The Senthong interior spatial system is formed from the Javanese people's life view which includes substance of trust, creativity, and aesthetic sensitivity. This means that visually the system forms a symbol aims to be enjoyed, felt and appreciated as the moral teachings for the next generation.

- Aspects relating to the dalem interior spatial system especially senthong include spatial layout, flow of circulation, functions and activities, symbols and ornament. The important aspects of Senthong make the Senthong entity an interesting cultural attraction to be drawn to the surface.

- Cultural attractions that represent cultural values and overshadow the presence of senthong interiors for Javanese people, so that the social status of the owner from nobles to ordinary people will influence the appearance of each type of Javanese traditional house.

3. The determinants that overshadow the visual culture in Senthong spatial system are:

The balance of society in carrying out kejawen and cosmos ideology is an important factor that overshadows the visual culture in the senthong spatial system of Javanese traditional house which is able to characterize the effectiveness of the system. Some elements of visual culture such as the pattern of spatial, spatial systems, symbolic forms and implied meanings are part of the representation of the Javanese philosophy of life. It is as a form of mindset for generations of nation who use messages from their ancestors as a basis for cultural conservation efforts.

It is not an easy thing to continue (preserve and maintain) a culture whose existence is threatened with extinction without our concern as a child of the nation in the present. This concern can be implemented by documenting, caring for and maintaining the originality of artifacts or writing and studying (conservation efforts) as material subjects that capable to cunstruct the mindset of the next generation to 
always guard the culture heritage as part of the tangible and intangible culture that is wealth of the nation.

\section{Suggestion}

This study requires alternative methods that are different and alternative objects, because there are other interesting things in the research. So that more in-depth research is needed and special discussion about the scope of this matter. Further research can focus more on observing the function of the house for personal (occupant) and social activities (community, in the context of referenced life philosophy) in the home category as a different object of observation, as well as an empowerment system of space functions for conservation efforts.

\section{References}

Dharsono (Sony Kartika). (2016). Kreasi Artistik (Perjumpaaan Tradisi Modern dalam Paradigma Kekaryaan Seni). Karanganyar: Citra Sain. LPKBN, p75; 95.

Cahyandari, G. O. I., "Tata Ruang dan Tata Elemen Arsitektur pada Rumah Jawa di Yogyakarta sebagai Wujud Kategori Pola Aktivitas dalam Rumah Tangga", Jurnal Arsitektur KOMPOSISI, Volume 10, Nomor 2, Oktober 2012.

Ismunandar. (2007). Joglo Arsitektur Rumah Tradsional Jawa, Semarang: Dahara Prize, p104.

Prijotomo, Josef. (1992). Forms of Javanese Architecture, Yogyakarta: Gadjah Mada University Press, p40.

Ronald, Arya.(2005). Nilai-nilai Arsitektur Rumah Tradisional Jawa, Yogyakarta: Gadjah Mada University Press, p44; p130-131; p145.

Slamet. (1984). Arsitektur Tradisional Daerah Jawa Tengah. Departemen Pendidikan dan Kebudayaan, Proyek Inventarisasi dan Dokumentasi Kebudayaan Daerah Jawa Tengah, p136-137.

Soeratman, Darsiti. (1989). Kehidupan Dunia Kraton Surakarta 1830-1039. Yogyakarta: Penerbit taman siswa, p89.

Sunarmi, dkk. (2007). Arsitektur dan Interior Nusantara. Surakarta: UNS press, p48.

Widayat, Rahmanu. "Krobongan Ruang Sakral RumahTradisi Jawa”, dalam Jurnal Demensi Interior Vol.2 No 1 Juni 2004: p.3 Jurusan Desain Interior, Fakultas Seni dan Desain Universitas Kristen Petra.

Zaini, Subarto. (2011). Leadership in Action. Jakarta:Elex Media Komputindo.

\section{Internet Reference:}

(https:/www.google.co.id/search?q=rumah+tradisional+jawa\&espv, Thursday, 22 Desember 2016:12.50). 